The Effect of Lactation Stage on the Hematological and Serum-Related Biochemical Parameters of the Travnik Pramenka Ewes

Utjecaj stadija laktacije na hematološke i biokemijske pokazatelje krvi ovaca Travničke pramenke

Antunović, Z., Mioč, B., Klir Šalavardić, Ž., Širić, I., Držaić, V., Đidara, M., Novoselec, J.

Poljoprivreda/Agriculture

ISSN: $1848-8080$ (Online)

ISSN: 1330-7142 (Print)

https://doi.org/10.18047/poljo.27.2.7

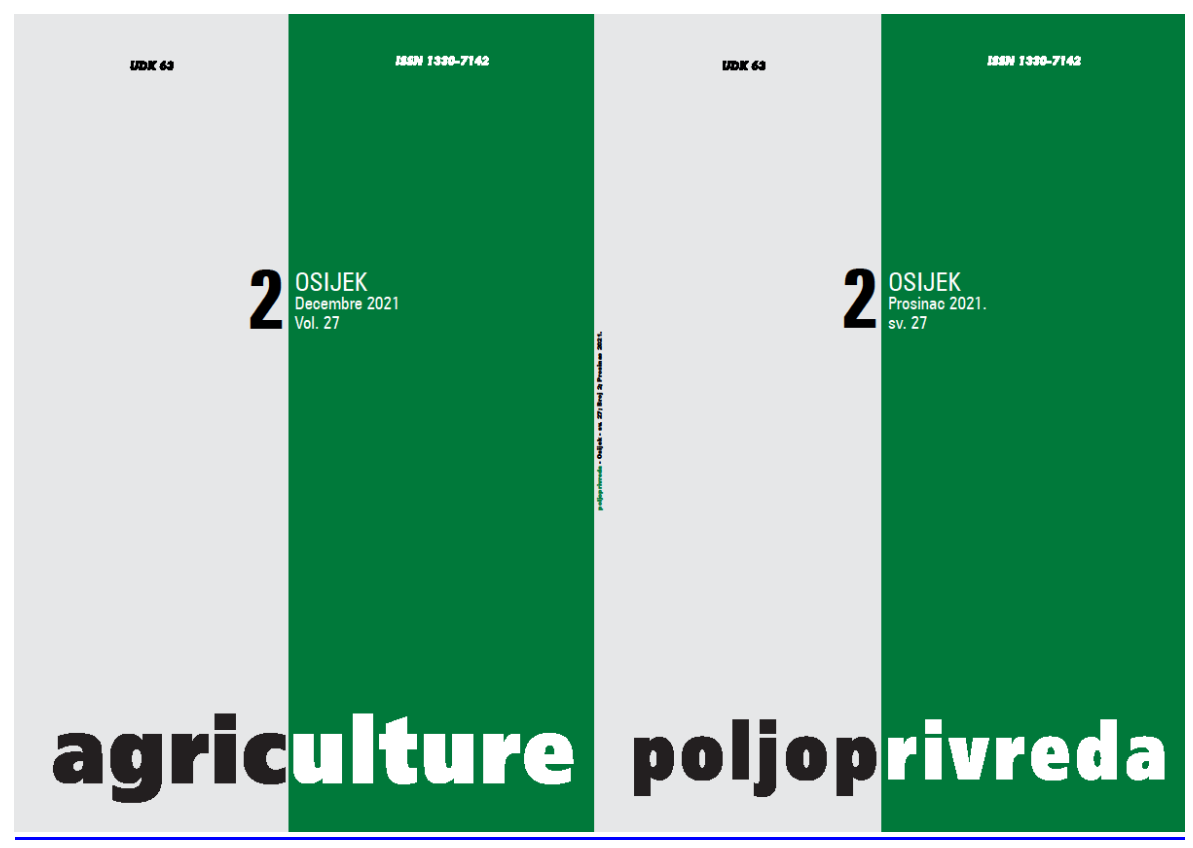

Fakultet agrobiotehničkih znanosti Osijek, Poljoprivredni institut Osijek

Faculty of Agrobiotechnical Sciences Osijek, Agricultural Institute Osijek 


\title{
THE EFFECT OF LACTATION STAGE ON THE HEMATOLOGICAL AND SERUM-RELATED BIOCHEMICAL PARAMETERS OF THE TRAVNIK PRAMENKA EWES
}

Antunović, Z. ${ }^{(1)}$, Mioč, B. ${ }^{(2)}$, Klir Šalavardić, Ž. ${ }^{(1)}$, Širić, I. ${ }^{(2)}$, Držaić, V. ${ }^{(2)}$, Đidara, M. ${ }^{(1)}$, Novoselec, J. ${ }^{(1)}$

Original scientific paper

Izvorni znanstveni članak

\begin{abstract}
SUMMARY
The aim of the present research was to determine the hematological and biochemical parameters of the Travnik pramenka ewes during lactation. Thirty-six ewes in average age of 3-5 years were included in the research. They were monitored in three stages of lactation: early, medium, and late stage. The WBC and RBC, HGB concentration, $\mathrm{HCT}$ and $\mathrm{MCH}$ values increased significantly as lactation progressed, while significant decrease of MCV and MCHC was determined in blood. HCT was slightly higher in the early compared to late stage, and the MCH in the medium compared to the late stage of lactation. A significant increase in the concentrations of $\mathrm{Ca}, \mathrm{P}, \mathrm{Mg}, \mathrm{Na}$ and $\mathrm{Cl}$, as well as a decrease of the Fe concentration was determined. As lactation progressed, the concentrations of urea, total proteins, albumin, globulin and BHB increased, as well as ALT activity. Contrary, concentrations of glucose and NEFA decreased, as well as GGT activity. Obtained results may help in monitoring the health and nutritional status of Travnik pramenka ewes. The effect of lactation stage needs to be included in the model when preparing the reference values for the blood parameters of Travnik pramenka ewes, particularly for RBC profiles, energy, and protein metabolites as well as liver enzymes.
\end{abstract}

Keywords: hematological parameters, biochemical parameters, stage of lactation, Travnik pramenka ewes

\section{INTRODUCTION}

The knowledge about normal blood values of different animals is of an academic as well as of a practical importance for clinical and experimental interpretations (Antunović et al., 2013 and 2017b). The determination and acquisition of knowledge for interpretation of hematological and biochemical parameters is very important for monitoring the metabolism and the health status of ewes (Kramer, 2000; Antunović et al., 2017a and b). The importance of hematalogical parameters lies in the fact that it allows the tracking of possible anomalies of hematocrit, erythrocyte morphology, or the alterations in the total or differential blood cell count (Kramer, 2000). Piccione et al. (2009) observed that, during lactation, the mammary gland secretory cells utilized $80 \%$ of the blood circulating metabolites aimed for milk synthesis, depending on the speed of infiltration of the free amino acids, glucose, fatty acids and other constituents. A strong reduction of lipogenesis and an increased concentration of fatty acids, which are supported by a norepinephrine and epinephrine stimulation, induce the increase in lipase activity in the mammary gland, providing the supstrate for milk synthesis (Nazifi et al., 2002). In early lactation, energy intake is below the animals needs, indicating a negative energy balance, which mobilizes the body reserves (Antunović et al., 2017a). The mobilization of body reserves firstly activates the body fat reserves and induces changes in the non-esterified fatty acids (NEFA) and $\beta$-hydroxybutyrate (BHB) concentrations in the blood serum (van Knegsel et al., 2007), as well as in some other serum constituents (insulin and glucose). LeBlanc (2010) concluded that the elevated serum NEFA

(1) Prof. Dr. Zvonko Antunović, Asst. Prof. Željka Klir Šalavardić (zklir@ fazos.hr), Assoc. Prof. Mislav Đidara, Assoc. Prof. Josip Novoselec Josip Juraj Strossmayer University of Osijek, Faculty of Agrobiotechnical Sciences Osijek, Vladimira Preloga 1, 31000 Osijek, Croatia, (2) Prof. Dr. Boro Mioč, Asst. Prof. Ivan Širić, Valentino Držaić Ph. D. - University of Zagreb, Faculty of Agriculture, Svetošimunska cesta 25, 10000 Zagreb, Croatia 
concentrations indicate a higher fat mobilisation rate, while an elevated BHB indicates the copleteness of lipid oxidation.

The sheep are well adapted to broad ranges of environment and physiological factors. The Travnik (Vlašićka, Dubska) pramenka has been bred in the western part of the Republic of Croatia since 1990, although the breed originates from Bosnia and Herzegovina. The Croatian breeders of the Travnik pramenka, in addition to the production of lambs (meat), produce the significant amounts of milk (around 70 to $130 \mathrm{~L}$ in lactation), which is most often processed into cheese. The Travnik pramenka is mostly reared extensively or semi-intensively, whereby almost the only feed for sheep is pasture (Novoselec et al., 2020). The hematological and serumrelated biochemical parameters of the Travnik pramenka were previously determined in Bosnia and Herzegovina (Hrković Porobija et al., 2019). According to Al-Hassan (2018), the metabolic profiles are used to evaluate an animal's health and to diagnose the metabolic diseases and nutritional status. However, comprehensive research in hematological and biochemical parameters of the Travnik pramenka ewes during lactation, as well as the hematological and serum-related biochemical parameters included in investigation of ewes, are missing. Thus, the aim of the present research is to determine the hematological and serum-related biochemical parameters in the Travnik pramenka ewes during different stages of lactation.

\section{MATERIALS AND METHODS}

The analyses of hematological and serum-related biochemical parameters were performed with regard to the Travnik pramenka ewes ( $n=36$ ) in age from three to five years, kept in an extensive production system in a herd numbering 1,000 sheep. They were monitored in different lactation stages: early $(40 \pm 5$ days of lactation), medium ( $80 \pm 5$ days of lactation), and late (120 \pm 5 days of lactation). The ewes used in the study were healthy and in a good physical condition. The ewes were grazing extensive pastures all day and returned to a stall afterwards to be fed with hay (ad libitum). Salt and water were offered to all ewes ad libitum.

The present research was carried out in the year 2019, when the examined ewes were in the third lactation and had single lambs in the litters. The family

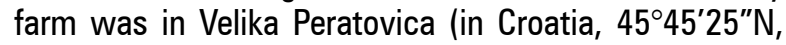
$\left.17^{\circ} 14^{\prime} 51^{\prime \prime} \mathrm{E}\right)$. In this Croatian region, the mean monthly temperature from May to July 2019 amounted to $19^{\circ} \mathrm{C}$, while the mean monthly rainfall was $113 \mathrm{~mm}$.

In Table 1, the feed composition is presented, determined by the standard methods (AOAC, 2006). The Kjeldahl method was used to determine the crude protein content of feed samples, while the Universal Extractions System B-811 (Buchi, Switzerland) was used to determine the ether extract. Ash was determined by incinerating the feed samples at $550^{\circ} \mathrm{C}$ for six hours. The amylase-treated neutral detergent fiber (NDF) was measured according to the EN ISO 1647:2006, while the acid detergent fiber (ADF) was measured according to the EN ISO 13906. Metabolizable and digestible feed energy for ewes was determined according to the DLG (1993). Mineral concentrations in the solutions of digested plant samples were determined by an inductively coupled plasma (ICP, PerkinElmer Optima 2100 DV).

Table 1. Chemical composition of pasture in diets of investigated ewes ( $\mathrm{mg} / \mathrm{kg} \mathrm{DM)}$

Tablica 1. Kemijski sastav pašnjaka na kojem su ovce napasane (mg/kg ST)

\begin{tabular}{|c|c|c|c|}
\hline \multirow[t]{2}{*}{ Parameters (g/kg DM) / Pokazatelj (g/kg ST) } & \multicolumn{3}{|c|}{ Green forage / Biljna masa } \\
\hline & 1 & 2 & 3 \\
\hline Crude proteins / Sirove bjelančevine & 155.3 & 193.4 & 241.8 \\
\hline Crude fiber / Sirova vlakna & 178.2 & 182.8 & 150.5 \\
\hline Crude ash / Sirovi pepeo & 89.4 & 87.4 & 84.3 \\
\hline Ether extract / Ekstrakt etera & 25.4 & 27.8 & 26.1 \\
\hline NDF, \% & 45.58 & 35.94 & 49.50 \\
\hline ADF, \% & 25.92 & 24.03 & 24.11 \\
\hline $\mathrm{DE}, \mathrm{MJ} \mathrm{kg}^{-1} \mathrm{DM}$ & 2.29 & 2.41 & 2.13 \\
\hline ME, MJ kg-1 DM & 2.01 & 2.10 & 1.84 \\
\hline \multicolumn{4}{|c|}{ Mineral content (mg/kg DM) / Sadržaj minerala (mg/kg ST) } \\
\hline $\mathrm{Ca}$ & 8870.84 & 7261.10 & 6986.36 \\
\hline $\mathrm{Mg}$ & 3395.83 & 1869.26 & 2755.74 \\
\hline K & 44769.84 & 39178.03 & 49822.06 \\
\hline$P$ & 5748 & 5857 & 5100 \\
\hline $\mathrm{Na}$ & 104.36 & 40.96 & 205.55 \\
\hline $\mathrm{Fe}$ & 226.60 & 207.90 & 274.30 \\
\hline $\mathrm{Se}$ & 0.052 & 0.047 & 0.066 \\
\hline
\end{tabular}

DM - dry matter / ST - suha tvar; NDF - neutral detergent fiber / NDF - neutralna deterdžentna vlakna; ADF - acid detergent fiber / ADF - kisela deterdžentna vlakna; DE - digestible energy / probavljiva energija; ME - metabolisable energy / metabolička energija 
Each ewe sample was obtained in each of the three lactation stages, always prior to grazing. The blood samples for a hematology analysis were taken from the jugular vein $(10 \mathrm{~mL})$ into two vacuum tubes (Venoject ${ }^{\circledR}$, Sterile Terumo Europe, Leuven, Belgium) containing an anticoagulant (EDTA). The determination of hematological parameters, like the white blood cell (WBC) count, red blood cell (RBC) count, hemoglobin (HGB) concentration, hematocrit (HCT) value, mean corpuscular volume (MCV), mean cell hemoglobin (MCH), mean cell hemoglobin concentration (MCHC) and platelet (PLT) count, was measured in the whole blood of the investigated ewes. The hematological parameters were measured by an automatic three differential hematology analyzer (PocH-100iV, Sysmex Europe GmbH, Hamburg, Germany). The Pappenheim method was used to determine a differential blood cell count by microscope, using the colored blood smears.

The blood samples for the determination of serumrelated biochemical values were collected in the vacuum tubes (Venoject ${ }^{\circledR}$, Sterile Terumo Europe, Leuven, Belgium) and were centrifuged at $1609.92 \mathrm{~g}$ within 10 minutes subsequent to the sampling to obtain the serum samples. The concentrations of minerals $\mathrm{(Ca}$, P-inorganic, $\mathrm{K}, \mathrm{Na}, \mathrm{Mg}$, chloride, and $\mathrm{Fe}$ ) were determined in serum. Likewise, the concentration of total proteins, albumin, urea, glucose, cholesterol, high-density lipoprotein (HDL), low-density lipoprotein (LDL), triglycerides (TGC), lactate, beta-hydroxybutirate (BHB) and nonesterified fatty acids (NEFA). The enzyme activities were determined in the serum, like aspartate aminotransferase (AST), alanine aminotransferase (ALT), alkaline phosphatase (ALP), Y-glutamyl transferase (GGT) and creatine kinase (CK), by the usage of Olympus System reagents (Olympus Diagnostic GmbH, Lismeehan, Ireland). The globulin content was calculated from the total protein and albumin difference. The Ranse/ ${ }^{\circledR}$ kit (Randox,
UK) was used to determine the activity of glutathione peroxidase (GPx), while the activity of total superoxide dismutase (SOD) in serum was determined using the Ransod (® kit (Randox, UK). All biochemical parameters and enzyme activities were carried out on an automatic Olympus AU 400 (Olympus, Japan).

The present study was carried out under the legal provisions according to the Animal Protection Act (Republic of Croatia's Official Gazette No. 133 [2006], No. 37 [2013], and No. 125 [2013]) as approved by Committee for Animal Welfare of Faculty of Agrobiotechnical Sciences Osijek

The results were treated by the MEANS procedure, while the effect of the lactation stage was analyzed by the GLM procedure, processed by the SAS $9.4^{\circledR}$. The means were compared by the Tukey's test, and the differences between the groups were declared significant at $\mathrm{P}<0.05$.

\section{RESULTS AND DISCUSSION}

The values of hematological parameters of the Travnik pramenka ewes during lactation were within the reference values (Kramer, 2000; Antunović et al., 2011). In the present study, a reduction of WBC at the earliest stage of lactation was determined (Table 2). These changes may be attributed to an increase in the cortisol level (as a result of an increased milk yield), which is probably responsible for the impairment of the cellular immune response (Caroprese et al., 2012). An opposite trend for the WBC in the ewes' blood was determined by Antunović et al. (2017b). Nozad et al. (2014) determined the statistical differences in the monthly values of hematological parameters (hemoglobin, erythrocyte, and leucocytes) in the Holstein dairy cows, which were within the normal range and could not be a consequence of infectious disorders.

Table 2. Hematological parameters and differential blood cell count of ewes in different lactation stages

Tablica 2. Hematološki pokazatelji i distribucija leukocita u ovaca tijekom različitih stadija laktacije

\begin{tabular}{|c|c|c|c|c|c|}
\hline & Early / Rani & Medium / Srednji & Late / Kasni & SEM & P-value / P-vrijednost \\
\hline WBC $\left(\times 10^{9} \mathrm{~L}\right)$ & $6.28^{\mathrm{a}}$ & $9.13^{b}$ & $8.97^{b}$ & 0.293 & $<0.001$ \\
\hline $\operatorname{RBC}\left(\times 10^{12} \mathrm{~L}\right)$ & $8.84^{\mathrm{a}}$ & $9.97^{b}$ & $9.85^{b}$ & 0.124 & $<0.001$ \\
\hline $\mathrm{HGB}(\mathrm{g} / \mathrm{L})$ & $98.15^{a}$ & $111.95^{b}$ & $114.61^{b}$ & 1.525 & $<0.001$ \\
\hline HCT (L/L) & $0.37^{\mathrm{a}}$ & $0.41^{\mathrm{b}}$ & $0.39^{\mathrm{ab}}$ & 0.006 & 0.021 \\
\hline $\operatorname{MCV}(\mathrm{fL})$ & $41.32^{\mathrm{a}}$ & $40.28^{\mathrm{ab}}$ & $39.46^{b}$ & 0.231 & 0.004 \\
\hline $\mathrm{MCH}(\mathrm{pg})$ & $11.08^{\mathrm{a}}$ & $11.24^{\mathrm{a}}$ & $11.66^{\mathrm{b}}$ & 0.065 & $<0.001$ \\
\hline $\mathrm{MCHC}(\mathrm{g} / \mathrm{L})$ & $270.10^{a}$ & $280.47^{a}$ & $296.29^{b}$ & 2.761 & $<0.001$ \\
\hline $\operatorname{PLT}\left(\times 10^{9} \mathrm{~L}\right)$ & 418.59 & 441.76 & 402.94 & 16.506 & 0.641 \\
\hline \multicolumn{6}{|c|}{ Differential blood cell count (\%) / Diferencijalna krvna slika (\%) } \\
\hline Lymphocytes / Limfociti & $61.92^{\mathrm{a}}$ & $53.05^{b}$ & $53.77^{b}$ & 1.165 & 0.001 \\
\hline Neutrophyls / Neutrofili & 34.49 & 37.68 & 33.39 & 1.118 & 0.270 \\
\hline Monocytes / Monociti & 0.256 & 0.447 & 0.226 & 0.079 & 0.470 \\
\hline Eosinophils / Eozinofili & $3.10^{\mathrm{a}}$ & $8.76^{\mathrm{a}}$ & $12.35^{\mathrm{c}}$ & 0.686 & $<0.001$ \\
\hline Basophils / Bazofili & 0.231 & 0.053 & 0.258 & 0.041 & 0.084 \\
\hline
\end{tabular}

SEM - standard error of mean / SEM - standardna pogreška srednje vrijednosti; a, b, c - values in rows with different letters differ significantly $(\mathrm{P}<0.05) / a, b, c-v r i-$ jednosti u redovima s različitim slovima značajno se razlikuju $(P<0,05)$; WBC - number of leukocytes / WBC - broj leukocita, $\mathrm{RBC}$ - erythrocytes / $R B C$ - broj eritrocita, HGB - hemoglobin / HGB - hemoglobin, HCT - hematocrit / HCT - hematokrit, MCV - mean corpuscular volume / MCV - prosječni volumen eritrocita, $\mathrm{MCH}$ - average hemoglobin content in erythrocytes / MCH - prosječna masa hemoglobina u eritrocitu, MCHC - mean hemoglobin concentration in erythrocytes / MCHC - prosječna koncentracija hemoglobina u krvi, PLT - platelet count / PLT - broj trombocita. 
This indicated an increased load of the ewes' organism during lactation period, which is reflected in the changes of hematological parameters. A differential blood cell count is very important because the changes in individual white cell types may occur simultaneously, leaving a total WBC count unchanged. Lactation is a very stressful period for an animal and the major contributor in various physiological variations (Kim et al., 2020). In the studies of Tsigai ewes in the first third of lactation, Antunović et al. (2011) have not detected significant differences in hematological parameters during the progress of lactation. Kim et al. (2020) suggested that a particular attention should be devoted to the hematological parameters such as the HGB, HCT, and RBC, which has demonstrated significant differences in various lactation stages of the Holstein cows.

Table 3. Blood minerals concentrations from ewes in different lactation stages

Tablica 3. Koncentracije minerala u krvi ovaca tijekom različitih stadija laktacije

\begin{tabular}{|l|c|c|c|c|c|}
\hline $\begin{array}{l}\text { Indicator, } \mathrm{mmol} / \mathrm{L} / \\
\text { Indikator, } \mathrm{mmol} / \mathrm{L}\end{array}$ & Early / Rani & Medium / Srednji & Late / Kasni & SEM & P-value / P-vrijednost \\
\hline $\mathrm{Ca}$ & $2.25^{\mathrm{a}}$ & $2.72^{\mathrm{b}}$ & $2.62^{\mathrm{b}}$ & 0.027 & $<0.001$ \\
\hline $\mathrm{P}$ & $1.18^{\mathrm{a}}$ & $1.81^{\mathrm{a}}$ & $2.08^{\mathrm{b}}$ & 0.038 & $<0.001$ \\
\hline $\mathrm{Na}$ & $126.82^{\mathrm{a}}$ & $130.18^{\mathrm{ab}}$ & $136.93^{\mathrm{b}}$ & 1.36 & $<0.001$ \\
\hline $\mathrm{K}$ & 6.00 & 6.27 & 6.58 & 0.41 & 0.201 \\
\hline $\mathrm{Mg}$ & $1.01^{\mathrm{a}}$ & $1.08^{\mathrm{b}}$ & $1.19^{\mathrm{c}}$ & 0.104 & $<0.001$ \\
\hline $\mathrm{Cl}$ & $106.67^{\mathrm{a}}$ & $112.87^{\mathrm{ab}}$ & $118.20^{\mathrm{b}}$ & 1.10 & $<0.001$ \\
\hline $\mathrm{Fe}(\mu \mathrm{mol} / \mathrm{L})$ & $28.02^{\mathrm{a}}$ & $23.02^{\mathrm{b}}$ & $21.62^{\mathrm{b}}$ & 0.623 & $<0.001$ \\
\hline
\end{tabular}

SEM - standard error of mean / SEM - standardna pogreška srednje vrijednosti; $a, b, c-$ values in rows with different letters differ significantly $(\mathrm{P}<0.05) / a, b, c-v r i$ jednosti u redovima s različitim slovima značajno se razlikuju $(P<0,05)$.

The lowest serum concentrations of $\mathrm{Ca}$ were determined in the early stage of lactation (Table 3), and the reason for this phenomenon could be an increased excretion of Ca through milk due to an increased milk production during the early lactation (Antunović et al., 2011). Calcium and phosphorus are mobilized from the bones similarly, although more calcium from the body and blood is excreted through milk (Codreanu and Calin, 2018). Liesgang et al. (2007) determined a lower concentration of $\mathrm{Ca}$ in the blood of ewes after lambing and in early lactation, which might be related to an increased secretion of $\mathrm{Ca}$ by milk and its rearrangement in bones. The same authors have detected an opposite trend for $\mathrm{Mg}$ concentrations. A significantly increased Ca concentration and an $\mathrm{Mg}$ and $\mathrm{P}$ concentration not significantly increased in the blood of cows from three to six and from 22 to 38 weeks of lactation were determined by Abdel-El-Naser et al. (2014). A significantly decreased Fe concentration in the blood of ewes during the progression of lactation could be induced by an increaesed excretion through milk. The similar results were determined by Antunović et al. (2011) in the Tsigai ewes during the first third of lactation. An increase of serum $\mathrm{Na}$ and $\mathrm{Cl}$ concentration in the lactating ewes from the 40th to the 60th day were determined by Codreanu and Călin (2018). The reason for this phenomenon could be a decreased excretion of electrolytes through milk due to a decreased milk production during the late lactation stage.

Table 4. Biochemical parameters in blood from ewes in different lactation stages

Tablica 4. Biokemijski pokazatelji u krvi ovaca tijekom različitih stadija laktacije

\begin{tabular}{|l|c|c|c|c|}
\hline $\begin{array}{l}\text { Indicator, mmol/L } \\
\text { Indikator, mmol/L }\end{array}$ & Early / Rani & Medium / Srednji & Late / Kasni & $\begin{array}{c}\text { P-value / } \\
\text { S-vrijednost }\end{array}$ \\
\hline Glucose / Glukoza & $3.46^{\mathrm{b}}$ & $3.64^{\mathrm{b}}$ & $4.90^{\mathrm{a}}$ & 0.104 \\
\hline Urea & $9.69^{\mathrm{a}}$ & $9.39^{\mathrm{a}}$ & $11.02^{\mathrm{b}}$ & 0.199 \\
\hline $\begin{array}{l}\text { Total proteins (g/L)/ } \\
\text { Ukupne bjelančevine (g/L) }\end{array}$ & $71.40^{\mathrm{a}}$ & $82.43^{\mathrm{b}}$ & $85.51^{\mathrm{c}}$ & 0.001 \\
\hline Albumin (g/L) & $28.69^{\mathrm{a}}$ & $31.42^{\mathrm{b}}$ & $30.69^{\mathrm{b}}$ & 0.002 \\
\hline Globulin (g/L) & $42.71^{\mathrm{a}}$ & $51.01^{\mathrm{b}}$ & $54.82^{\mathrm{c}}$ & 0.679 \\
\hline CHOL & 2.10 & 2.09 & 1.99 & 0.001 \\
\hline HDL & 1.41 & 1.35 & 1.29 & 0.037 \\
\hline LDL & 0.59 & 0.60 & 0.56 & 0.001 \\
\hline TGC & 0.29 & 0.31 & 0.30 & 0.019 \\
\hline NEFA & $0.38^{\mathrm{a}}$ & $0.14^{\mathrm{b}}$ & $0.13^{\mathrm{b}}$ & 0.009 \\
\hline BHB & $0.27^{\mathrm{a}}$ & $0.37^{\mathrm{b}}$ & $0.39^{\mathrm{b}}$ & 0.027 \\
\hline
\end{tabular}

SEM - standard error of mean / SEM - standardna pogreška srednje vrijednosti; $a, b, c$ - values in rows with different letters differ significantly (P<0.05) / a, b, $c$ vrijednosti u redovima s različitim slovima značajno se razlikuju $(P<0,05)$; CHOL - cholesterol / CHOL - kolesterol, HDL - high-density lipoprotein / HDL - lipoproteini visoke gustoće, LDL - low-density lipoprotein / LDL - lipoproteini male gustoće, TGC - triglycerides / TGC - trigliceridi, NEFA - non-esterified fatty acids / NEFA - neesterificirane masne kiseline, BHB - $\beta$-hydroxybutyrate / BHB - $\beta$-hidroksibutirat. 
The energy status assessment in the examined ewes was performed by the determination of glucose, cholesterol, HDL, LDL, tryglicerides, NEFA and BHB concentrations in blood, while urea, total protein, and albumin concentration, as well as a CK activity, were used as the indicators of ewes' protein supply by feed (Antunović et al., 2017a). Significantly lower concentrations of NEFA and glucose and a higher BHB in blood of early lactating sheep in the present study indicate an energy deficit. In a pronounced negative energy balance, the intensive lipomobilization mostly leads to a decreased extend of gluconeogenesis, followed by hypoglycemia at the beginning of lactation (Doepel et al., 2002). A lowered concentration of glucose in the blood of early lactating dairy cows was determined by Abd-El Naser (2014). After lambing, a decrease in the NEFA and an increase in the BHB concentrations have indicated a negative energy balance when lipomobilization stops (Douglas et al., 2006;). Pesántez-Pacheco et al. (2019) have determined the highest levels of BHB and the smallest levels of NEFA in a postpartum period of high-yielding ewes, which means that these changes had occurred earlier than in the low-yielding ewes. In the present study, a blood NEFA concentration $(0.38$ $\mathrm{mmol} / \mathrm{L}$ ) in early lactation shows evidence of a high lipomobilization. The increase of NEFA and BHB concentrations in the blood of ewes in early lactation, along with a decreased glucose in blood, could also reflect a low energy intake by the ewes. An increase in both the NEFA and glucose concentrations, along with a decrease in $\mathrm{BHB}$ in the blood of ewes during a medium and late stage of lactation, indicate a satisfactory energy supply by sheep at the later stages of lactation. During the dairy cows' medium lactation stage, the serum NEFA concentration were relatively low because an energy balance becomes positive when the cows supply a tissue reserve (Walters et al., 2002). A significant increase of glucose concentration in blood, as well as the total proteins, urea, and triglycerids in the ewes' blood, affected by a lactation stage, was also determined by Codreanu and Calin (2018).

Table 5. Blood enzymes activities from ewes in different lactation stages

Tablica 5. Aktivnosti enzima u krvi ovaca tijekom različitih stadija laktacije

\begin{tabular}{|l|c|c|c|c|c|}
\hline $\begin{array}{l}\text { Enzyme, U/L/ } \\
\text { Enzim, U/L }\end{array}$ & Early / Rani & Medium / Srednji & Late / Kasni & SEM & P-value / P-vrijednost \\
\hline AST & 138.62 & 154.64 & 181.37 & 10.195 & 0.245 \\
\hline ALT & $21.05^{\mathrm{a}}$ & $26.12^{\mathrm{b}}$ & $24.22^{\mathrm{b}}$ & 0.531 & $<0.001$ \\
\hline ALP & 163.54 & 206.34 & 173.92 & 10.810 & 0.225 \\
\hline GGT & $60.16^{\mathrm{a}}$ & $50.02^{\mathrm{b}}$ & $52.85^{\mathrm{b}}$ & 1.457 & $<0.001$ \\
\hline CK & 278.31 & 181.05 & 119.55 & 25.386 & 0.125 \\
\hline SOD, U/mL & 0.31 & 0.29 & 0.34 & 0.013 & 0.386 \\
\hline GPx & 251.20 & 217.35 & 257.57 & 25.160 & 0.792 \\
\hline
\end{tabular}

SEM - standard error of mean / SEM - standardna pogreška srednje vrijednosti; $\mathrm{a}, \mathrm{b}, \mathrm{c}$ - values in rows with different letters differ significantly $(\mathrm{P}<0.05) / \mathrm{a}, \mathrm{b}, \mathrm{c}-$ vrijednosti u redovima s različitim slovima značajno se razlikuju $(P<0,05)$; AST - aspartate aminotransferase / AST - aspartat aminotransferaza, ALT - alanine aminotransferase / ALT - alanin aminotransferaza, ALP - alkaline phosphatase / ALP - alkalna fosfataza, GGT - v-glutamyl transferase / GGT - V-glutamil transferaza, CK - creatine kinase / CK - kreatin kinaza, SOD - superoxide dismutase / SOD - superoksid dismutaza, GPx - glutathione peroxidise / GPx - glutation peroksidaza.

The concentration of urea in the blood of ewes in the medium and late lactation stages have significantly increased, as compared to an early stage. A similar phenomenon was observed by Antunović et al. (2017a) and Roubies et al. (2006), who reported that this could either be due to an increased deamination or due to an increased protein intake. Abdelatif et al. (2009) determined a gradual increase of urea concentration in the lactating ewes along with the lactation, which was possibly due to an increase in the feed intake, related to the higher nutrient demads.

In the present study, the differences between lactation concerning the blood cholesterol and triglycerides were not significant, although a decrease is evident. A similar conclusion was derived by Kim et al. (2020) in the Holstein cows during various lactation stages, suggesting that a particular attention should be devoted to the biochemical parameters and enzyme activity determination in blood, such as the concentrations of urea, glucose, NEFA and BHBA, as well as to the activities of ALT and GGT that have manifested significant differences in various lactation stages. In the present study, the GGT was within the reference values for sheep (15-60 U/L; Kaneko et al., 2008). A significantly higher activity of ALT, as well as a nonsignificant activity of AST in the ewes' blood during the lactation progress, could be related to the quality of diet (pasture). Radkowska and Herbut (2014) found that a high concentration of nitrogen compunds in pasture may influence the nitrogen metabolism in liver, which could be manifested by the higher serum activities of ALT and AST. Roubies et al. (2006) concluded that a more intense liver function of lactating ewes was due to the higher requirements for energy and proteins, necessary for the maintenance and milk production. Similar results with the Merinolandscaft ewes during lactation were found by Antunović et al. (2017a). 


\section{CONCLUSION}

In the present study, the differences of the most of hematological and serum biochemicals were determined in the Travnik pramenka ewes during lactation. The effect of the lactation stage needs to be included in the model when preparing the reference values for the blood parameters of the Travnik pramenka ewes, particularly for the RBC profiles, energy, and protein metabolites, as well as for the liver enzymes. The obtained results may be helpful in monitoring the health and nutritional status, as well as in the ewe management improvement.

\section{ACKNOWLEDGEMENTS}

The study was carried out within the Research Team Innovative Breeding and Technological Processes in Animal Production (No. 1126) at the Faculty of Agrobiotechnical Sciences 0sijek.

\section{REFERENCES}

1. Abd-El Naser, E. M., Mohamed, G. A., \& Elsayed, H. K. (2014). Effect of lactation stages on some blood serum biochemical parameters and milk composition in dairy cows. Assiut Vet. Med. J, 60, 83-88.

https://doi.org/10.21608/avmj.2014.170968

2. Abdelatif, A. M., El-Nageeb, M. E., Makawi, S. E. A., \& Fadlalla, A. M. (2009). Blood constituents in cycling, gestating and lactating desert ewes (Ovis aries) in relation to dietary supplementation. Global Veterinaria, 3(3), 248-259.

3. Al-Hassan, M. J. (2018). Metabolic Profiles of Healthy Pre-and Post-Partum Aardi Goats (Capra hircus) and Kids in Saudi Arabia. Pakistan Veterinary Journal, 38(4), 424-428.

https://doi.org/10.29261/pakvetj/2018.080

4. Antunović, Z., Novoselec, J., Šperanda, M., Vegara, M., Pavić, V., Mioč, B., \& Djidara, M. (2011). Changes in biochemical and hematological parameters and metabolic hormones in Tsigai ewes blood in the first third of lactation. Archives Animal Breeding, 54(5), 535-545. https://doi.org/10.5194/aab-54-535-2011

5. Antunović, Z., Novoselec, J., Klir, Ž., \& Đidara, M. (2013). Hematological parameters in the Alpine goats during lactation. Poljoprivreda, 19(2), 40-43.

6. Antunović, Z., Novoselec, J., Šperanda, M., Steiner Z., Ćavar, S., Pavlović, N., Valek Lendić, K., Mioč, B., Paćinovski, N., \& Klir, Ž. (2017a). Monitoring of blood metabolic profile and milk quality of ewes during lactation in organic farming. Mljekarstvo/Dairy, 67(4).

7. Antunović, Z., Novoselec, J., \& Klir, Ž. (2017b). Hematological parameters in ewes during lactation in organic farming. Poljoprivreda, 23(2), 46-52.

8. AOAC (2006). Official methods of analysis of AOAC International. Association of Analytical Communities, Arlington, Virginia, USA.

9. Caroprese, M., Albenzio, M., Bruno, A., Annicchiarico, G., Marino, R., \& Sevi, A. (2012). Effects of shade and flaxseed supplementation on the welfare of lactating ewes under high ambient temperatures. Small Ruminant Research, 102(2-3), 177-185.

10. Codreanu, I., \& Calin, S. (2018). Investigations regarding the influence of the physiological status on some electrolytic, enzymatic and biochemical blood parameters in ewes. Revista Romana de Medicina Veterinara, 28(4), 5-13.

11. DLG (1993). Futterwerttabellen für wiederkäuer, 6 Auflage, Frankfurt am Main.

12. Doepel, L., Lapierre, H., \& Kennelly, J. J. (2002). Peripartum performance and metabolism of dairy cows in response to prepartum energy and protein intake. Journal of Dairy Science, 85(9), 2315-2334.

13. Douglas, G. N., Overton, T. R., Bateman II, H. G., Dann, H. M., \& Drackley, J. K. (2006). Prepartal plane of nutrition, regardless of dietary energy source, affects periparturient metabolism and dry matter intake in Holstein cows. Journal of Dairy Science, 89(6), 2141-2157. https://doi.org/10.3168/jds.S0022-0302(06)72285-8

14. Hrković Porobija, A., Vegara, M., Hodžić, A., PašićJuhas, E., Softić, A., Ohran, H. (2019). The Influence of Geographic Area on Blood Parameters of Pramenka Sheep in the Area of Bosnia and Herzegovina. Turkish Journal of Veterinary Research, 3(1), 1-8.

15. Kaneko, J. J., Harvey, J. W., and Bruss, M. L. (2008). Clinical Biochemistry of Domestic Animals. 6th ed. Elsevier/Academic Press, Amsterdam. pp. 931.

16. Kim, S. B., Jung, S. H., Do, Y. J., Jung, Y. H., Choe, C., Ha, S., Jeong, H. Y., Cho, A., Oh, S., Kim, E., Yoo, Y. G., \& Kim, S. (2020). Haemato-chemical and immune variations in Holstein cows at different stages of lactation, parity, and age. Veterinární medicína, 65(3), 95-103. https://doi.org/10.17221/110/2019-VETMED

17. Kramer, J. W. (2000). Normal hematology of cattle, sheep and goats. Schalm's veterinary hematology, 5, 1075-1084. LeBlanc, S. (2010). Monitoring metabolic health of dairy cattle in the transition period. Journal of Reproduction and Development, 56(S), S29-S35. https://doi.org/10.1262/jrd.1056S29

18. Liesegang, A., Risteli, J., \& Wanner, M. (2007). Bone metabolism of milk goats and sheep during second pregnancy and lactation in comparison to first lactation. Journal of animal physiology and animal nutrition, 91(56), 217-225. https://doi.org/10.1111/j.1439-0396.2007.00695.x

19. Nazifi, S., Saeb, M., \& Ghavami, S. M. (2002). Serum lipid profile in iranian fat-tailed sheep in late pregnancy, at parturition and during the post-parturition period. Journal of Veterinary Medicine Series A, 49(1), 9-12. https://doi.org/10.1046/j.1439-0442.2002.00405.x

20. Novoselec, J., Gregurinčić, I., Klir, Ž., Mioč, B., Širić, I., Držaić, V., \& Antunović, Z. (2020). The estimation of body weight from body measurements of Travnik Pramenka sheep in the area of Bilogora, Croatia. Journal of Central European Agriculture, 21(2), 207-214. https://doi.org/10.5513/JCEA01/21.2.2667

21. Nozad, S., Ramin, A. G., Moghaddam, G., Asri-Rezaei, S., \& Kalantary, L. (2014). Monthly evaluation of blood hematological, biochemical, mineral, and enzyme 
parameters during the lactation period in Holstein dairy cows. Comparative Clinical Pathology, 23(2), 275-281.

22. Pesántez-Pacheco, J. L., Heras-Molina, A., TorresRovira, L., Sanz-Fernández, M. V., García-Contreras, C., Vázquez-Gómez, M., Feyjoo P., Feyjoo, P., Cáceres, E., Frías-Mateo, M., Hernández, F., Martínez-Ros, P., González-Martin, J. V., González-Bulnes, A., \& Astiz, S. (2019). Maternal metabolic demands caused by pregnancy and lactation: association with productivity and offspring phenotype in high-yielding dairy ewes. Animals, 9(6), 295. https://doi.org/10.3390/ani9060295.

23. Piccione, G., Caola, G., Giannetto, C., Grasso, F., Runzo, S. C., Zumbo, A., \& Pennisi, P. (2009). Selected biochemical serum parameters in ewes during pregnancy, postparturition, lactation and dry period. Animal Science Papers and Reports, 27(4), 321-330.

24. Puppel, K., \& Kuczyńska, B. (2016). Metabolic profiles of cow's blood; a review. Journal of the Science of Food and Agriculture, 96(13), 4321-4328. https://doi.org/10.1002/jsfa.7779
25. Radkowska, I., \& Herbut, E. (2014). Hematological and biochemical blood parameters in dairy cows depending on the management system. Animal Science Papers \& Reports, 32(4).

26. Roubies, N., Panousis, N., Fytianou, A., Katsoulos, P. D., Giadinis, N., \& Karatzias, H. (2006). Effects of age and reproductive stage on certain serum biochemical parameters of Chios sheep under Greek rearing conditions. Journal of Veterinary Medicine Series A, 53(6), 277-281. https://doi.org/10.1111/j.1439-0442.2006.00832.x

27. Van Knegsel, A. T. M., Van den Brand, H., Graat, E. A. M., Dijkstra, J., Jorritsma, R., Decuypere, E., ... \& Kemp, B. (2007). Dietary energy source in dairy cows in early lactation: metabolites and metabolic hormones. Journal of Dairy Science, 90(3), 1477-1485. https://doi.org/10.3168/jds.S0022-0302(07)71633-8

28. Walters, A. H., Pryor, A. W., Bailey, T. L., Pearson, R. E., \& Gwazdauskas, F. C. (2002). Milk yield, energy balance, hormone, follicular and oocyte measures in early and mid-lactation Holstein cows. Theriogenology, 57(2), 949-961.

\section{UTJECAJ STADIJA LAKTACIJE NA HEMATOLOŠKE I BIOKEMIJSKE POKAZATELJE KRVI OVACA TRAVNIČKE PRAMENKE}

\section{SAŽETAK}

Cilj ovoga istraživanja bio je utvrditi hematološke i biokemijske pokazatelje u krvi ovaca travničke pramenke tijekom laktacije. Istraživanje je provedeno na 36 ovaca prosječne dobi od tri do pet godina tijekom triju stadija laktacije: ranoga, srednjeg i kasnog. WBC i RBC, koncentracija HGB-a te vrijednost HCT-a i MCH-a značajno su se povećavali tijekom laktacije, dok je utvrđeno i značajno smanjenje vrijednosti MCV-a $i$ MCHC-a u krvi. Sadržaj HCT-a bio je viši u ranome stadiju u odnosu na kasni stadij laktacije, a sadržaj MCH-a u srednjem stadiju u odnosu na kasni stadij laktacije. Utvrđeno je značajno povećanje koncentracije $\mathrm{Ca}_{\mathrm{a}} \boldsymbol{P}_{\mathrm{\prime}}$ Mg, $\mathrm{Na}$ i Cl tijekom laktacije, kao i smanjenje koncentracije Fe. Kako je laktacija napredovala, utvrđeno je povećanje koncentracije ureje, ukupnih proteina, albumina, globulina i BHB-a te aktivnosti ALT-a. Suprotno tome, koncentracije glukoze i NEFA-e su se smanjile, kao i aktivnost GGT-a. Dobiveni rezultati mogu pomoći u praćenju zdravstvenoga i hranidbenog statusa travničke pramenke. Stoga je u model za utvrđivanje referentnih vrijednosti krvi ovaca travničke pramenke potrebno uključiti utjecaj stadija laktacije, osobito za RBC, energetske i proteinske metabolite te jetrene enzime.

Ključne riječi: hematološki pokazatelji, biokemijski pokazatelji, stadij laktacije, travnička pramenka

(Received on October 21, 2021; accepted on November 10, 2021 - Primljeno 21. listopada 2021.; prihvaćeno 10. studenoga 2021.) 